\title{
The Subversion of Identity from Princesses to Queens - A Cultural Study on Feminism in Maleficent
}

\author{
Jialiang Chen \\ School of English for International Business, Guangdong University of Foreign Studies, Guangzhou, China \\ Email address: \\ 20190310011@gdufs.edu.cn

\section{To cite this article:} \\ Jialiang Chen. The Subversion of Identity from Princesses to Queens - A Cultural Study on Feminism in Maleficent. International Journal of \\ Literature and Arts. Special Issue: Humanity and Science: China's Intercultural Communication with the Outside World in the New Era. \\ Vol. 8, No. 3, 2020, pp. 127-133. doi: 10.11648/j.ijla.20200803.14
}

Received: February 27, 2020; Accepted: March 10, 2020; Published: April 8, 2020

\begin{abstract}
Disney films have long been known as adapting classic fairy tales or legends from all over the world and creating distinctive princess images, among which, the development of different princess images manifests relative values in corresponding periods. Maleficent is adapted from the animated film Sleeping Beauty with similar story arrangements on the continuation of Sleeping Beauty as the main line. With the witch Maleficent as the narrative subject, the film subverts the traditional image of the witch under the patriarchal discourse, especially with respect to the subversion of the characters and themes. The deconstruction and reconstruction of the characters of different genders based on feminism shows the marginalization of male characters and the centralization of the female characters. The film is also characterized by postmodernism, reflecting the clinginess of the theme to the feminist values the US intends to convey. The subversion of characters and themes in the film is the product of the current social environment, which not only captures the spirit of the age, but also conforms to the psychological expectations of the audience in the new era. The paper first gives a general introduction and then provides a relevant literature review on feminism as well as postmodernism, and the development of feminism displayed in Disney princess films in different periods. Next, the paper analyzes the film Maleficent based on its progress from previous films, the centralization and marginalization of characters and the subversion of the theme, describing women's resistance to patriarchy and the subversion of identity. Last, the paper draws a conclusion and comments on the values of feminism delivered from Disney films.
\end{abstract}

Keywords: Disney Princess, Feminism, Subversion, Deconstruction and Reconstruction, Postmodernism

\section{Introduction}

As a mirror of social life and culture, films have a lot to do with the times during different periods. In films, the establishment of identity conforms to the psychological requirement and expectation of the audience for a particular type of characters so that contemporary social and cultural identity can be reflected to a certain degree. Stereotypes will be presented in the film by means of the setting of characters, namely a fixed impression of a specific group of people formed by social classifications such as gender, age, occupation, race, etc, which is largely in line with the public expectation of the characters [1]. The setting of characters is relevant to the era background and social reality, thus attracting the potential audience and promoting the box office.
During the past century, Disney's animated films have become one of the crucial cultural symbols for the export of American values [2]. Based on classic fairy tales or legends from all over the world, Disney has created distinctive princess images, most of which are based on western fairy tales such as Grimm's fairy tales and Andersen's fairy tales. The term Disney Princess was officially put forward in 2000 by Andy Mooney, chairman of Disney's Consumer Department, as a concept of the collection of the series of characters of Disney princesses in the Disney's animated films [3]. From Snow White (1937) as the emergence of the first princess film to Frozen II (2019), 24 princesses animated films have been released, shaping the roles of the 14 princesses with different skin colors and different personalities. For a long time, Disney's animated films have received high praise for their appeal to audiences of different 
ages.

All fairy tales are intended for adults, which do not meet the psychological needs of children but serve as the psychological metaphor of the adult society [4]. In recent years, with the popularity of the feminist movement, Disney princess films are developing gradually from a single narrative paradigm to the subversion of the original type, interpreted as the continuous marginalization of the male role as the articulation for female social status. Disney films are endowed with a rich connotation of the present time, making the female characters, especially princesses in the film more colorful, more vivid and more complex so that it breaks the stereotype of women in the previous stage [5] and therefore reconstructs the image of women in the new era.

\section{Literature Review}

\subsection{Feminism \& Postmodernism}

\subsubsection{Feminism}

Feminist theories are the explanation of women's subordination [6]. Taking social gender as an analytical category from the standpoint of socially constructed gender, feminism questions the assumptions and prejudices of women in various fields of natural sciences and humanities, re-recognizes various so-called objective, neutral and natural norms, items and disciplines existing in the current society, challenges traditional ideology, and presets traditional disciplines, producing new viewpoints as well as theories of social gender on the basis of critical thinking, thus promoting the improvement or transformation of women's status in society [7]. The main point of feminism is to oppose the patriarchy in the traditional ideology, abandon the western male-centrism, reject the monopoly of speech right of men, and rebuild the female discourse system to achieve the deconstruction and reconstruction of the culture centered on patriarchal system from the standpoint, expression and experience of women [8]. With the popularity of postmodernism, feminists are willing to deconstruct themselves and their groups. Traditional female images have been widely criticized, and women's pursuit is not only limited to political equality, but also more focused on spiritual equality, exploration of self-value and struggle for equal rights.

A new and successful branch of contemporary feminism is ecofeminism, proposed by French radical feminist Francoise $\mathrm{d}$ 'eaubonne in 1974. As the latest trend of western feminism, ecofeminism is one of the most dynamic factions of feminism [9]. From the pluralistic culture perspective, ecofeminism emphasizes women in the subordinate position of dominance and the nature ruled by human [10], opposes all forms of oppression and violence [11], and declines everything to do with governance to struggle against power not only concerning the change of the main body, but also the subversion of the power structure itself [12]. With the emphasis on the inner connection between women and nature, the two concepts of fighting for equality between men and women and protecting the ecological environment are organically linked with the purpose of both improving the relationship between men and women and fixing the relationship between human and nature [13] to replace the world view emphasizing dominance and transform it into another value system. Ecological feminist claim that women have their natural identity [14], and the oppression on both women and nature has a direct connection, encouraging women to struggle against men and anthropocentrism, advocate the change of the thinking pattern of the rule governing nature, criticize the patriarchal values, eulogize the nature of women, and oppose values leading to the governance, exploitation, aggression so that an equal society where men and women, human and nature, live in harmony can be established [15-17]. Ecological feminism advocates regarding men and women, human and non-human nature as equal partners, rather than the relationship of control or domination [18], refutes the dual domination of patriarchy over nature and women, and strives to build a harmonious society in which man and nature live peacefully and equally. In a patriarchal society, women have little or even no speech right [19], but as the feminist movement develops, women try to struggle and manage to have their speech right step by step.

\subsubsection{Postmodernism}

Postmodern culture is rooted in real life and reflects people's inner pursuit of happiness. From the perspective of postmodernism, the phenomenon of central marginalization and marginal centralization emerges in popular culture, reflecting relevant clinginess and subversion at the same time. Literary and cultural works are supposed to follow and promote certain aspects of mainstream culture, as Fiske [20] puts it, "meaning and pleasure in popular culture never escape the power to generate dominant phenomena"... This trait is called the clinginess of popular culture [21]. As John Fiske [20] says, "the essential characteristic of popular cultural works lies in their ability to trigger people's opposition, resist and even change the power to generate dominant phenomena", so as to stimulate the audience's resonance at a deeper level. Such characteristic refers to the subversion of popular culture [21].

As one of the typical representatives of the post-modern cultural period, films play an effective role in conveying values for its "immediacy, universality, directness, pleasure and education [22]". Writers in different periods adapted classic narrative methods and literary prototypes and incorporated them into their creations to cater for the tastes of the audience [23]. To a certain degree, Disney has transformed and made adjustments to fairy tales as a tool to convey its ideology. For one thing, the production and distribution of films are expected to be in line with the current trend and echo the values conveyed by the government. For another, in order to win the box office, the film is supposed to make adjustments to the contents in order to subvert the traditional paradigm. 


\subsection{Disney Princesses and Feminism}

\subsubsection{Stage One (from the 1930s to the 1960s): Beautiful and Vulnerable, Waiting for Redemption}

In the $1930 \mathrm{~s}$, feminism in the United States was just in its infancy, when the public still expected women to be the vassal of men [2]. In the early Disney princess films, the princesses' happy lives were based on the marriage with a good man, generally a prince. The princesses in Snow White, Cinderella and Sleeping Beauty were innocent and kind, ignorant of the dangers of society and the complexity of human nature. They suffered because of simplicity and survived due to kindness. No matter how many setbacks they encountered, they still held a firm belief that happiness would eventually fall upon them naturally. They held an optimistic attitude towards life and looked forward to a bright future [24]. In addition, princesses were often desire-free and had no ambition of pursuing dreams. The princesses tended to be attached to men so that all their hopes in life were pinned on love, desiring to use love to achieve the change of fate, quietly waiting for the prince's appearance and redemption, with the final ending of falling in love with the prince at first sight, and marrying the prince to live a happy life ever after [2], which was a common paradigm in the early Disney princess movies. In a patriarchal society, the princesses were kind and beautiful, while the princes were always handsome and powerful, acting as the savior, which clung to the values intended by the government during that period.

Snow White even established the classic Disney princess image, of prettiness and kindness, singing and dancing, and making friends with small animals [24]. The humble, mild, marriage-seeking princess only became a hit during Snow White. However, the following series such as Cinderella and Sleeping Beauty failed to live up to expectations, discouraging Disney from making a princess film in approximately 30 years.

\subsubsection{Stage Two (from the 1960s to the 1980s): Adventurous and Courageous, Striving for Life}

The feminism in this period deconstructed the model of ideal woman advocated by the society, and called on women to go out of the house, change their life to care more about themselves, and give full play to their intelligence and potential [25]. Influenced by feminism in this stage, the princesses were different from the original paradigm in that they were submissive to everything. They dared to resist, and pursued happiness and freedom with their wisdom and courage.

From Beauty and the Beast on, the princess was no longer the same as before but with rebellious ideas and their own independence. Pocahontas was Disney's first attempt at a non-white princess, while Mulan was based on a Chinese story in which women were no longer beautiful and delicate, but confident and brave. However, Mulan finally returned to her hometown, which seemed to endow women with speech right in some sense, but actually put women back into the family [26]. The selection of these princesses become diversified, with the image of princesses deconstructed and reconstructed in a way, enabling them to have speech right on some level, but the main speech right was still in the hands of men.

\subsubsection{Stage Three (from the 1990s to the 21st Century): Independent and Dedicated, Seeking for Self-actualization}

From the late 1990 s, with feminist movements entering the latest stage, women have gained increasing understanding and respect, and feminism has developed from fighting against men to how to get along with men [27]. With the trend of feminism and postmodernism sweeping the world, many post-modern elements characterized by deconstruction and non-centralism are reflected in many Disney films as well, making many traditional female characters subverted and reinterpreted in a post-modern context [28]. Without the black-and-white boundary between good guys and bad guys at the beginning, films of this period show the complexity of human nature with diverse characters.

During this period, Disney's representative works include the Princess and the Frog, Rapunzel, Brave, Frozen, Maleficent and so on. In this stage, the princesses finally managed to accomplish their self-salvation; that is, they disdained to be princesses merely, but wanted to be queens in charge of the kingdom. Only after establishing a relatively comprehensive understanding of themselves can they liberate themselves, realizing that the company of the family plays a far more significant role compared with illusory love.

\section{A Critical Analysis on Feminism in Maleficent}

\subsection{From Frozen to Maleficent}

As an influential representative during the third stage, Frozen dramatically breaks through the previous paradigm of the fallen princess waiting for the prince to redeem, and sisterhood replaces the love between the princess and the prince. The concept it intends to convey is gradually grounded and integrated into contemporary people's views, especially on love [5]. The princesses are no longer waiting for the princes to redeem them; instead, they can grasp their own destiny and the initiative to pursue their own happiness (see 2.2.3). Love at first sight is unnecessarily true love, and a prince is unnecessarily a perfect lover. The villain prince Hans is handsome and considerate on the surface, but in fact turns out to be a sinister pretender to the throne [29]. After experiencing self-repression and self-denial, Elsa finally integrated into the social mainstream, fulfilling the reconstruction of her own identity and the marginalization of the other, and assuming her social responsibilities. Anna's redemption shows that women, as independent individuals, can get rid of their reliance on male power and do not need to return to their families. Passiveness and confusion are replaced by freedom and independence, promoting the achievement of the subversion and establishment of self-identity accordingly. 
During the third stage till Frozen, films managed to make substantive adjustments to the traditional cognition of women in Disney films and re-examined princess films from the perspective of feminism, which can be regarded as a giant step forward in the advancement of feminism. But Frozen also has its limitations: the princess's awakening is not a complete awakening, but a self-imposed exile from male domination based on an isolated castle from human nature. While the male image has been subverted, it still implies in details the normative force of male power on women to a certain degree. Even in the end, the princesses can only get comfort via the utopia of sisterhood in Frozen, and complete the self-salvation of women.

Comparatively, in Maleficent, the feminist standpoint is further sublimated and faced up to, with the image of "whitewashing witch" as the voice of the stigmatized women [28], and a fair view of the status and role of women that their ability and talent should not be negated and buried. Women also have speech right and they have the ability to save the world as well.

\subsection{The Marginalization of Male Roles}

\subsubsection{The King}

The king in Sleeping Beauty, as the embodiment of kingship and the representative of patriarchy, loved his daughter very much and did his best to protect her. He was presented as a good king and a good father, which is a typical image in the traditional patriarchic society. Nevertheless, as Maleficent's biggest villain in Maleficent, his role has been subverted as an unwholesome, evil and incompetent king, born in a peasant family from the very beginning, who had lost both parents since childhood and was in humble status without necessary family education. He once entered the forest to steal gems, but was not severely punished by Maleficent after being caught, and the two even became intimate friends with the so-called "true love's kiss" when Maleficent was 16 years old, which echoes Maleficent's later irony of true love's kiss with the curse on the princess that nothing but the true love's kiss can save the princess.

In the film, due to his treachery, his lonely and impoverished life and his desire for money and power, he finally coaxed his lover into drinking and cut off her wings cruelly in order to gain the favor of the original king and became the successor afterwards. After the witch cast a curse on his daughter, he was unexpectedly heartless, for he only cared about himself, becoming angry, frustrated, full of hatred, and wanted to kill the witch, in spite of their previous relationships. The king was no longer brave or responsible in comparison with those in previous fairy tales as he was afraid of being killed and sent soldiers to arrest Maleficent, while he had no desire but to merely hide in the castle. He had no affection, as he was completely unmoved when he was called to see the dying queen, and meanwhile ignored his daughter despite a long time without meeting each other, continuing drowning himself in how to catch and kill the witch. During adventures to save the princess, Maleficent was trapped by his layout, but succeeded later in breaking through the siege and pressed him at a disadvantage. While the witch's initial intention was to free the king, the evil king did not stop but wanted to cruelly sneak attack from behind, only to fall down to death from the castle. The heroic image of the king in the film is completely deconstructed and reconstructed, which subverts the perfect male image in the prototype of the fairy tale. The male-centrism is strongly impacted. The king is no longer an admirable character, making the authority greatly undermined and compromised.

\subsubsection{The Prince}

The prince in Sleeping Beauty could be defined as a real hero who was noble, handsome, brave and fearless to cut through the thorns to rescue the princess, kill the witch and wake up the princess with the true love's kiss. However, the prince in Maleficent has been completely marginalized, and his heroic image has been reduced to a supporting role. While the prince was still handsome and fell in love with the princess at first sight, two people had no time for further exchanges before the princess became a sleeping beauty. With the identity totally subverted, ironically, the role of the prince in the film was only to kiss the princess awake. When the prince gave the true love's kiss, the princess was still asleep, which implied that the true love's kiss between men and women seemed very weak, for they only met each other once without any further communication, let alone true love. Instead, it was Maleficent who broke the curse and awakened the princess with a kiss of genuine motherly love. The role of the prince became useless in the film, which subverted the traditional fairy-tale image of the typically perfect prince and the paradigm of men rescuing women. At the end of the film, the prince witnessed the coronation of the princess, and they just smiled at each other. Their relationship was more like a friendship than a couple, breaking the traditional pattern that the prince and the princess should be bound to marry and live a happy life ever after.

\subsubsection{The Crow}

In Sleeping Beauty, the witch's crow was just a bird without any detailed description, whereas the crow in Maleficent was the male servant of the witch. Such a setting of strong female and weak male overturned the traditional fairy tale's image of the female as the weak and male as the strong, reflecting the resistance of female rights to the dominance of male power. The crow was her servant, her comrade in arms, standing beside her in her hour of distress and her companion, silently tolerating her bad temper and accompanying her around with joys and sorrows. There is no doubt that from the perspective of feminism, ability has nothing to do with gender, and it is not uncommon for women to be strong and men to be weak.

\subsection{The Centralization of Female Roles}

\subsubsection{The Witch (Maleficent)}

The witch, as a villain in Sleeping Beauty living in an isolated mountain with various beasts and especially a black crow as her pet, was typically the traditional image of evil 
forces in Disney films in our mind. It was just because the king did not invite her to the princess's birthday celebration that she placed a curse on the princess. Meanwhile, in order to prevent the prince from coming to the rescue, she turned into a dragon to confront him, but was eventually stabbed to death by the prince with a sword.

Whereas, the dark witch in Maleficent, no longer had a single evil personality, but more complexity and humanity. Her pale face, fiery lips, high cheekbones and long, eerily horned hair did not frighten viewers, but rather caused them to sympathize with her misfortune. Her wings were cut off by the king, and his cruel and brutal aggression forced her to become so dark that she lost her unique feminine tenderness, which was enough to explain her motive for casting such a cruel curse on the princess. When she woke up and found that her wings had been cut off, all the screams she uttered were deeply felt by the audience, accompanied by the awakening of her revenge on the king, which implied that women should not be placed at the mercy of men, but strive for their own rights. When she arrived unexpectedly at the princess's birthday celebration and put the curse on the princess, the king, in the confrontation with her, knelt down to beg for her daughter's life, she shouted "I like your begging", as the ultimate outburst of her anger. The curse was a total irony of the so-called true love's kiss that happened to the witch and the king (see the excerpt below). During the days when the princess was supervised and cared for by three incompetent elves, Maleficent took over the role of "godmother" taking care of her and keeping her safe. As time went on, her hatred faded and she even blamed herself for casting such a curse on the innocent princess simply for her father's fault. As the prince failed to wake up the princess with the so-called true love's kiss, the witch showed his guilt by kissing her on the forehead, but accidentally managed to wake her up, which could be interpreted as true love's kiss from mother. This kind of setting is unpredictable but understandable. True love does not necessarily come from prince and princess, and love from family members or close friends also counts. True love should not be what happens at the first sight but on a deep and time-tested basis.

Excerpt (the curse in the film): Before the sunset on her sixteenth birthday, she will prick her finger on the spindle of a spinning wheel and fall into a sleep like death, a sleep from which she will never awaken... The princess can be woken from her death sleep, but only by true love's kiss. This curse will last till the end of the time! No power on earth can change it.

\subsubsection{The Princess}

The princess in Sleeping Beauty fell asleep basically most of the time, therefore making the time spent with the king very limited. At the same time, as a representative of the positive image of women in the film, undoubtedly she would not run the other way to follow the witch and betray her father. However, although the princess in Maleficent was also far away from their parents and lived with three elves, she was not afraid of the witch, and even considered her as her fairy godmother, growing up under the witch's careful protection, and building a deep mother-daughter relationship with Maleficent. When the king wanted to kill Maleficent, the princess knew right from wrong and determinedly helped her fairy godmother to get the sealed wings, regain her power and defeat the king. At the end of the film, Maleficent realized the unification of the human kingdom and the kingdom of the moss forest, placing it to the princess, which meant that women could be leaders as well. The subversion of the role of princess reflects the female's resistance to the patriarchy in the post-modern context, and shows the female's independent personality.

\subsection{The Subversion of the Theme}

With the establishment of the patriarchal society, the status of the witch declined and witches assumed the shadow prototype, becoming the embodiment of evil [28], as shown in many Disney films such as Sleeping Beauty. More often than not, the struggle against the witch is actually a struggle of justice against the evil of humans in the fairy tale. Since the 1970s, with the trend of feminism and postmodernism, many post-modern elements characterized by deconstruction and reconstruction have also been reflected in Disney films, making many traditional characters subverted and reinterpreted based on the post-modern context and perspective, as presented in Maleficent.

In Maleficent, evil is not inherent in the witch. The witch blackened because the king's betrayal caused the witch to curse the princess. The shadow archetype in the film is embodied in men (see 3.2.1), which is a typical story written from the perspective of feminism, which tries its best to express the ugly, greedy, contradictory and tangled irony reflected in the patriarchal society. This kind of change is an active declaration of the battle against the injustice of men and women in the patriarchal society, indicating that the source of evil does not necessarily come from women, but from the low status of women [28]. Maleficent deeply reflects on the evil brought by male power in the patriarchal society and the injustice to women, so a new witch image emerges with flesh and blood, love and justice, represented with a modern appearance.

Sleeping Beauty promotes the theme that true love ranks over all, and that the good ranks over the evil, leading the audience to believe that love at first sight and a kiss for love between a man and a woman are real, perfect and expected. Therefore, the princess lies on the bed passively waiting for the rescue of the prince, showing the image of female weakness and dependence on male imposed by patriarchy on women, considered as "home angel", similar to housewives. On the contrary, intelligent, rebellious and unyielding women were regarded as witches who are not welcome and acceptable. Maleficent subverted the theme of Sleeping Beauty, making fairy tale love at first sight questioned by modern people. The king never believed in true love, and the prince's so-called true love's kiss failed to wake up the sleeping princess. True love does not have to be a romantic love between a man and a woman, let alone love at first sight, for true love exists between mother and daughter as well [30], 
based on which the film portrays a complicated side of human nature.

Feminists believe that love has nothing to do with money or status, and that love at first sight is not true love, which, whether in family or in love, needs to be built over time. The prince's kiss is not from true love, unable to save the princess, while the witch's motherly love for the princess is interpreted as true love that has been tested over time. The love-at-first-sight myth has been overturned and eliminated, turning the old myth of true love into a new myth form [31], which is unpredictable but understandable, thus proposing a completely new understanding of true love.

\subsection{Further Representation in Maleficent II}

In Maleficent II (2019), the representation of feminism has been dramatically developed compared with Maleficent (2014). The king was cursed by the queen to fall into sleep like death, which was the intrigue of the human queen to challenge Maleficent, triggering the conflict between Maleficent, the princess and the human queen. From Sleeping Beauty (1959), in which the princess sleeps most of the time, to Maleficent II, the identities of both male and female are completely subverted to an unprecedented level; that is, the speech right is entirely transferred from men to women. Furthermore men, the king and the prince, have lost their speech right fundamentally and fail to play a certain part in the film.

Maleficent II, as the sequel, fails to meet the audience's tone and gains less public praise compared with the first film, so it is described, to a certain extent, as a film without any innovation or creativity. Regardless of other aspects beyond the thesis, the relatively exaggerated representation of feminism in the film has led to criticism from some audiences. Is there an overemphasis on feminism for the opposite of the gender setting of Sleeping Beauty; that is, are women endowed with excessive speech right? Is feminism represented for the mere sake of feminism? Further suggested research on feminism in Disney films can be carried out based on such a phenomenon of "over-feminism".

\section{Conclusion}

In the past, Disney films of the audience adopted the victory of good over evil to refresh the spirits over and over again, release their inner pressure, and satisfy their psychological needs. However, the film Maleficent adapted from the traditional fairy tale Sleeping Beauty, especially in the aspect of the subversion of the identity of characters, embodies the post-modern feminist resistance to traditional patriarchy-centered viewpoint, sharing the perspective of feminism to treat true love and redemption, and singing praises to the great selfless maternal love, harmony between man and nature, along with a social equality between men and women. Women try to break the tradition, have certain speech right and establish their own discourse system based on the deconstruction and reconstruction of their roles. Feminism regards deep and time-tested love as true love in total contrast to love at first sight [32]. Only this kind of true love can effectively redeem women themselves, and ultimately manage to redeem others.

The story of post-modern Disney films can be depicted as the growth of human beings. It is a growth story of self-examination and self-conquest, which unifies the harmonious relationship between environmental protection, ecology, man and nature. The subversion of the identity of characters is a symbol of the impact of feminism, and reflects its inevitability under the feminist theory in the post-modern context, which enriches the art treasury of Disney and satisfies the aesthetic needs of modern people.

\section{References}

[1] Huang Jialiang. (2005). "On the root of social discrimination and its elimination -- social discrimination from the perspective of social psychology," Ideological Front, (05): pp. 89-93.

[2] Zhang Shuoyan. (2019). "Analysis of female stereotypes and social prejudices in animated films -- a case study of the transmutation of princess images in Disney films," Journal of Press Research, 10 (15): pp. 29-30+32.

[3] Wu Yun and Qin Linyu. (2019). "Innovation mechanism analysis of Disney princess movies in the new century," China Film Market, (07): pp. 22-26.

[4] Hua Jing. (2014). "Feminism, female status and female image -- on the transmutation of princess image in the classic American Disney cartoons," New film, (06): pp. 96-99.

[5] Wang Zhujun. (2014). "On the changes of female characters in Disney animation in recent years from Frozen," Popular Literature and Art, (12): pp. 193-194.

[6] Li Yinhe. (1997). The rise of women's power. Beijing: China Social Sciences Press, pp. 91.

[7] Liu Liqun. (2004). Gender and media communication. Beijing: Communication University of China Press, pp. 19.

[8] Zhang Bo. (2017). "Deconstruction and construction -feminist consciousness perspective of the film Maleficent," Film Review, (11): pp. 74-76.

[9] Wu Lin. (2011). Research on the critical theory and practice of American ecofeminism. Beijing: People's Publishing House.

[10] Karen J. Warren. (2000). Ecofeminist philosophy: a western perspective on what it is and why it matters. Lanham: Rowman \& Littlefield Publishers Inc.

[11] Ynestra King. (1989). Healing the wounds: feminism, ecology and nature /culture dualism. Alison Jaggar, Susan Bordo, eds. Gender/Body/Knowledge: feminist reconstructions of being and knowing. New Brunswick and London: Rutgers University Press, pp. 20.

[12] Starhawk. Power. (1990). Authority and mystery: ecofeminism and earth-based spirituality. Irene Diamond, Gloria Feman Orenstein, eds. Rewearing the world: the emergence of eco-feminism. San Francisco: Sierra Club Books, pp. 77.

[13] Nangong Meifang, Zhu hongmei, Wu tiantian and Lv lita. (2011). Eco-feminism: a literary interpretation of gender, culture and nature. Beijing: Social Sciences Academic Press, pp. 1. 
[14] Lu Shuyuan. (2000). Ecological literature and art. Xi'an: Shaanxi People's Education Press.

[15] Cao Nanyan and Liu bing. (1996). "Eco-feminism and its significance," Philosophical Research, (05): pp. 54-60.

[16] Chen Weihua. (2004). "A new perspective on the relationship between man and nature -- the natural view of eco-feminism," Science, Technology and Dialectics, (05): pp. 33-34.

[17] Wu Lin. (2010)." The origin of western ecofeminism," Journal of Central South University: Social Sciences, (6): pp. 142-146.

[18] Tan Sining. (2014). "Ecological feminist interpretation of Maleficent," Film Literature, (23): pp. 103-104.

[19] Chen Kaiju. (2010). Cultural research of speech right. Guangzhou: Sun Yat-sen University Press.

[20] Fiske, John. (1989) Understanding popular culture. London: Unwin Hyman.

[21] Chen Kaiju. (2004). "On the clinginess and subversion of popular culture from the perspective of the sketch 'Red Sorghum Model Team'," Jiangxi Social Sciences, (06): pp. 181-184.

[22] Chen Kaiju. (2018). Post-modern cultural entertainment criticism. Beijing: Intellectual Property press.

[23] Ye Xiaojun. (2014). "On the value orientation of Maleficent," Film Review, (20): pp. 32-34.

[24] Miao Yufei. (2008). "Evolution of Disney princess animation from a gender perspective," Journal of Chifeng University (Chinese philosophy and social sciences edition), 39 (08): pp. 120-123.

[25] Jin Li. (2009). "American feminist movement, feminist literature and feminist criticism," American Studies, (01): pp. 62 .

[26] Wang Mengyao. (2016). "Sisterhood in Disney films -- a case study of Frozen and Maleficent," Journal of News Research, 7 (03): pp. 116-117.

[27] Zhang Hanjiao. (2018). "A study on the image of the heroine in Disney animated films," Science and Technology Information, 16 (25): pp. 238-239.

[28] Zhou Lai. (2016). "The modern transformation of witches in Disney films -- from Sleeping Beauty to Maleficent," Beauty and Times (Part 1), (02): pp. 73-75.

[29] Chi Yunling, and Zhao Yuhong. (2016). "The evolution of Disney princesses from Frozen," Film Literature, (23): pp. 117-119.

[30] Wang Jing. (2015). "A comparative study of Maleficent and Sleeping Beauty," New Film, (03): pp. 126-128.

[31] Li Saike. (2014). "Making the myth of true love -- a semiotic analysis of Disney animated films Frozen and Maleficent," Film Review, (13): pp. 12-13.

[32] Tian Yiwan. (2016). "Interpretation of female salvation and love in the movie Maleficent," Film Review, (16): pp. 68-70. 